\title{
Errors in Case Markers Made by Syrian Students Who Learn Turkish in Temporary Education Center
}

\author{
Mustafa Onur Kan ${ }^{1}$, Gizem Utlu ${ }^{1}$ \\ ${ }^{1}$ Department of Elemantary Education, Mustafa Kemal University, Turkey \\ Correspondence: Mustafa Onur Kan, Department of Elemantary Education, Mustafa Kemal University, Turkey.
}

Received: July 30, 2017

Accepted: August 16, 2017

Online Published: August 24, 2017

doi:10.11114/jets.v5i9.2562

URL: https://doi.org/10.11114/jets.v5i9.2562

\begin{abstract}
The purpose of this study is to determine the errors in case markers in the texts formed by Syrian students, who learn Turkish as a foreign language. The study group of this research, which is designed as a case study, comprises of a total of 60 Syrian students in A1 and A2 level, studying in the temporary education center of Al-Nassaj, which is affiliated with the district of Antakya, Hatay. The determination of the levels of the students was based on the description of the linguistic competences proposed by The Common European Framework of Reference for Languages (CEFR). A placement test was administered to the students in line with the description proposed by the CEFR, and a total of 30 students in A1 and 30 students in A2 were included to the study. A personal information form as well as writing forms, which had been developed by the researchers, were employed in the data collection. The analysis of the data obtained from the writing forms was performed through descriptive analysis method. An evaluation meeting was held with a faculty member specialized in the field of Turkish education in order to ensure the reliability of the data, and a consensus has been reached on the data.

The study revealed that in terms of the total number of words used by the students, the students in A1 made 8 errors in case markers for each 100 words whereas those in A2 made 9.3 errors in case markers for each 100 words. It is remarkable that the students in A1 made the most errors in the genitive case markers whereas those in A2 made the most errors in locative case markers. There was no error in the ablative case markers in the texts produced by the students in A1. The study further found that the number of such errors made by the students in A2 was very low.
\end{abstract}

Keywords: temporary education center, case markers, Syrian students

\section{Introduction}

According to the 2016 of Turkey General Directorate of Migration Management, a total of 2.957.454 Syrians lives in Turkey. Based on the Turkey Ministry of National Education data, as part of the educational services offered in Turkey, it is reported that 459.521 people are provided with education, 166.482 of whom receive their education in state schools whereas 293.39 of whom study at temporary education centers (TECs) (Education Reform Initiative, 2017). There are 432 TECs in Turkey, most of which are located in Hatay (Education Reform Initiative, 2017). In these centers, Syrians receive education in their native language, and they are further participating in Turkish courses by Turkish lecturers for 15 hours a week (Turkey General Directorate of Migration Management, 2016). These data point out the necessity of establishing a long-term educational policy in Turkey.

Writing, one of the four basic skills, enables an individual to express their feelings and ideas in a concrete way (Kan \& Tiryaki, 2015). As written expression is one of the most essential components of human life, training and education and language and fulfils a major need, it is particularly important (İnal, 2006). It is necessary to perform studies on grammar, which examines the building blocks of a language, besides studies on the four basic linguistic skills, so that an individual can express their opinions in line with the rules of such language and in a way that reflects its aesthetics values (Islığlu, 2014). The students learning Turkish as a foreign language need to have profound knowledge of Turkish grammar rules in order to use their writing skills in an effective way.

When the students learning Turkish as a foreign language, unless their native language is an agglutinative language, first encounter the agglutinative language of Turkish, they have difficulty until they grasp the linguistic logic of Turkish; therefore, it is important that the grammar rules of Turkish should be simplified as much as possible and taught in an effective way to foreign students (Tunçel, 2013). Arabic is an inflected language and the stems of words change when a 
new word is derived or inflected. On the other hand, the stems of words in Turkish do not change during inflection and derivation. The studies (Melanlığlu, 2012; Duman, 2013; Demirci \& Dinçaslan, 2016; Yılmaz \& Temiz, 2015) reported that foreign students have various difficulties in learning Turkish suffixes.

Case markers are the markers that denote the case of a noun when it establishes a temporary semantic relation between nouns and verbs in a sentence (Korkmaz, 2009). According to Aksan (1989), one of the difficulties, indeed, the most important one, that a foreign student encounters when starting to learn Turkish, is the proper use of case markers. Bölükbaş (2011) argues that one of the reasons for the errors in case markers in Turkish made by Arabic students is the negative transfer from their native language. These being said, it may be stated that the students who learn Turkish as a foreign language, particularly those whose native language structure is very different from the structure of Turkish, might have various difficulties in using case markers.

In the literature, the studies on the case markers in the texts formed by the students learning Turkish as a foreign language (Altaş Özkan, 1992; Güven, 2007; Yıldırım, 2011; Arhan, 2015; Yılmaz Atagül \& Yahşi Cevher, 2015) were generally performed with the students studying in Turkish and Foreign Language Research and Application Center (TÖMER) and with the students preparing for the university admission test. This study was carried out with the students at primary and secondary school level, who study at TECs, as distinct from the above-mentioned studies. For that reason, this study, based on the texts formed by the students at a lower level and a younger age group, will potentially contribute to the discussions on case markers in the literature. Further, this study might provide some insights into the errors in case markers made by the students for the teachers teaching Turkish to Syrian students, particularly in TECs.

This study aims to determine the errors in case markers in the texts formed by Syrian students learning Turkish as a foreign language.

\section{Method}

\subsection{Research Model}

This is a case study analysing the errors in case markers in the texts formed by Syrian students. A case study, which is one of the qualitative research designs, examines the factors related to a case (environment, individuals, events, processes, etc.) based on a holistic approach and focuses on how these factors affect and are affected by the case (Yıldırım \& Şimşek, 2016).

\subsection{Study Group}

The study group of this research consists of a total of 60 Syrian students in A1 and A2, studying in the temporary education center of Al-Nassaj, affiliated with the district of Antakya in Hatay in the 2016-2017 academic year. The study group was selected through the criterion sampling approach. The basic principle in the criterion sampling approach is to study any case that meets a predetermined set of criteria (Yıldırım \& Şimşek, 2016: 122). In this sense, the fundamental criterion set by the researchers was that the Turkish language levels of the Syrian students studying at a $\mathrm{TEC}$ are required to be $\mathrm{A} 1$ and $\mathrm{A} 2$.

The determination of the levels of the students was based on the description of the linguistic competences proposed by The Common European Framework of Reference for Languages (CEFR). A placement test was administered to the students in line with the description proposed by the CEFR, and a total of 30 students in A1 and 30 students in A2 were included to the study. The characteristics of the students are as follows:

10 of the students in A1 were male whereas 20 of them were female. In terms of age, 12 of them were between 9-11 years old, and 18 of them were between 12-14 years old. The number of the students who speak a language other than their native language was 4. The students speak English as their foreign language. 9 of the students have been residing in Turkey for 1 year; 7 of them for 2 years; 4 of them for 3 years; 5 of them for 4 years and 5 of them for 5 years. A total of 16 students have been learning Turkish for 1 year and 14 of them have been learning Turkish for 2 years.

6 of the students in A2 were male whereas 24 of them were female. In terms of age, 8 of them were between 9-11 years old, and 19 of them were between 12-14 years old; and the other 3 were between 15-16 years old. The number of the students who speak a language other than their native language was 6 . The students speak English as their foreign language. 2 of the students have been residing in Turkey for 1 year; 7 of them for 2 years; 7 of them for 3 years; 8 of them for 4 years and 6 of them for 5 years. A total of 9 students have been learning Turkish for 1 year; 13 of them for 2 years; and 8 of them for 3 years.

\subsection{Data Collection and Analysis}

A personal information form as well as writing forms, which had been developed by the researchers, were employed in the data collection. The topics in these forms were revised according to the levels of the students and reviewed by two Turkish education specialists. The topics in the writing forms are as follows: 
Topics for writing for the students in A1

- Please write about yourself.

- In which district is the school that you attend in Hatay? Please write a text describing the location of the school.

- What is your favorite season? Please write what happens in that season.

Topics for writing for the students in A2

- Please write a text to introduce any profession.

- What is your favorite movie? Please tell about the movie.

- Please write a text describing a trip you have made.

The students in A1 and A2 were asked to choose one of the three above-mentioned topics and to form a text about it.

The analysis of the data obtained from the writing forms was performed through descriptive analysis method. Accordingly, the data obtained are summarized and interpreted based on the pre-determined themes (Yıldırım \& Şimşek, 2016: 239). An evaluation meeting was held with a faculty member specialized in the field of Turkish education in order to ensure the reliability (see. Merriam, 2009) of the data, and a consensus has been reached on the data.

\section{Findings}

The total number of words used in the texts formed by the students in A1 was 730 whereas the total number of words used in the texts formed by the students in A2 was 970 . Table 1 shows the frequency of the errors in case markers in the texts formed by the students in A1 and A2.

Table 1. The frequency of the errors in case markers by the students in A1 and A2

\begin{tabular}{lll}
\hline The type of the error & A1 (f) & A2 (f) \\
\hline The errors in the locative case markers & 15 & 34 \\
The errors in the dative case markers & 9 & 27 \\
The errors in the accusative case markers & 16 & 16 \\
The errors in the genitive case markers & 18 & 10 \\
The errors in the ablative case markers & 0 & 3 \\
Total & 58 & 90
\end{tabular}

As seen in Table 1, there was a total of 58 errors in the case markers in the texts formed by the students in A1. The study revealed that the students in A1 made the most errors in the genitive case markers $(\mathrm{f}=18)$ whereas they made the least errors in the dative case markers ( $\mathrm{f}=9)$. Further, it is notable that they did not make any error in the ablative case markers. On the other hand, there was a total of 90 errors in the case markers in the texts formed by the students in A2. The study found out that the students in A2 made the most errors in the locative case markers $(f=34)$ whereas they made the least errors in the ablative case markers $(\mathrm{f}=3)$.

The study concluded that in terms of the total number of words used by the students, the students in A1 made 8 errors in case markers for each 100 words whereas those in A2 made 9.3 errors in case markers for each 100 words.

Table 2 shows the frequency of the errors in accusative markers in the texts formed by the students in A1 and A2.

Table 2. The frequency of the errors in accusative case markers by the students in A1 and A2

\begin{tabular}{lll}
\hline The errors in accusative case markers & A1(f) & A2(f) \\
\hline Lack of an accusative case marker & 14 & 13 \\
Using a dative case marker rather than an accusative case & 0 & 3 \\
marker & & 0 \\
$\begin{array}{l}\text { Using a locative case marker rather than an accusative case } \\
\text { marker }\end{array}$ & 2 &
\end{tabular}

As seen in Table 2, the errors in the accusative case markers made by the students in A1 and A2 were mostly due to the lack of an accusative case marker. Below, there are some examples from the texts formed by the students in relation to the errors in the accusative case markers. 
Lack of an accusative case marker

A1:

$$
\text { Ben Tirkye Gok seveyormm }
$$

A2:

$$
\text { cucoktarcok seviyorlar }
$$

Using a locative case marker rather than an accusative case marker

A1:

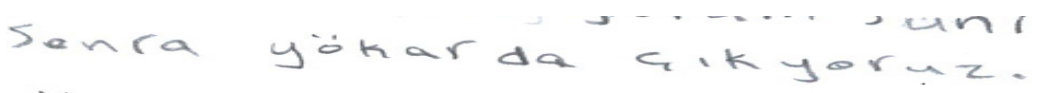

Using a dative case marker rather than an accusative case marker

A2:

$$
\text { oğretmen Bize Dovmez }
$$

Table 3 shows the frequency of the errors in genitive markers in the texts formed by the students in A1 and A2.

Table 3. The frequency of the errors in genitive markers in the texts formed by the students in A1 and A2

\begin{tabular}{lll}
\hline The errors in genitive case markers & A1(f) & A2 (f) \\
\hline Lack of a genitive case marker & 12 & 6 \\
Redundant use of a genitive case marker & 9 & 1 \\
\hline
\end{tabular}

As seen in Table 3, the errors in the genitive case markers made by the students in A1 and A2 were mostly due to the lack of a genitive case marker. Below, there are some examples from the texts formed by the students in relation to the errors in the genitive case markers:

Lack of a genitive case marker

A2:

$$
\text { Ben U. Kisilits ai lemvar }
$$

Redundant use of a genitive case marker

A2:

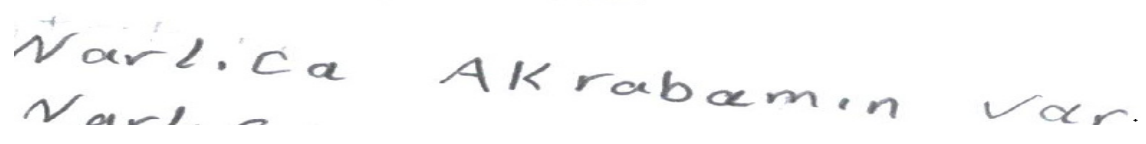

Table 4 shows the frequency of the errors in dative case markers in the texts formed by the students in A1 and A2.

Table 4. The frequency of the errors in dative case markers by the students in A1 and A2

\begin{tabular}{lll}
\hline The errors in dative case markers & A1(f) & A2(f) \\
\hline Lack of a dative case marker & 6 & 21 \\
$\begin{array}{l}\text { Using a locative case marker rather than a dative case } \\
\text { marker }\end{array}$ & 3 & 4 \\
$\begin{array}{l}\text { Redundant use of a dative case marker } \\
\text { Using an accusative case marker rather than a dative case }\end{array}$ & 0 & 1 \\
marker
\end{tabular}

As seen in Table 4, the errors in the dative case markers made by the students in both A1 and A2, but predominantly in those in A2, were mostly due to the lack of a dative case marker. Below, there are some examples from the texts formed by the students in relation to the errors in the dative case markers: 
Lack of a dative case marker

A1:

\section{BPr Almasa jokulu gidiuoruy?}

A2:

$$
\text { ögretmen Annen gölica oki }
$$

Using a locative case marker rather than a dative case marker

A1:

$$
\text { Ben altinci sinifta gidiyorm. }
$$

Using an accusative case marker rather than a dative case marker

A2:

$$
\text { ögretmen onu ceza verdi }
$$

Redundant use of a dative case marker

A2:

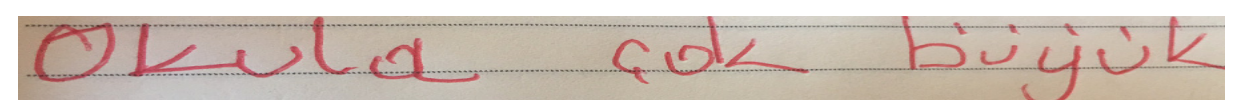

Table 5 shows the frequency of the errors in locative case markers in the texts formed by the students in A1 and A2.

Table 5. The frequency of the errors in locative case markers by the students in A1 and A2

\begin{tabular}{lll}
\hline The errors in locative case markers & A1(f) & A2(f) \\
\hline Lack of a locative case marker & 14 & 31 \\
$\begin{array}{l}\text { Using a dative case marker rather than a locative case } \\
\text { marker }\end{array}$ & 1 & 2 \\
$\begin{array}{l}\text { Using an ablative case marker rather than a locative } \\
\text { case marker }\end{array}$ & 0 & 1
\end{tabular}

As seen in Table 5, the errors in the locative case markers made by the students in both A1 and A2 were mostly due to the lack of a locative case marker. Below, there are some examples from the texts formed by the students in relation to the errors in the locative case markers:

Lack of a locative case marker

A1:

$$
\text { Tanein deniz ruseriz }
$$

A2:

$$
\begin{aligned}
& \text { Ben antakyada lokanta yemek } \\
& \text { Yedim parka gittim sonva arabalara }
\end{aligned}
$$

Using a dative case marker rather than a locative case marker 
A1:

A2:

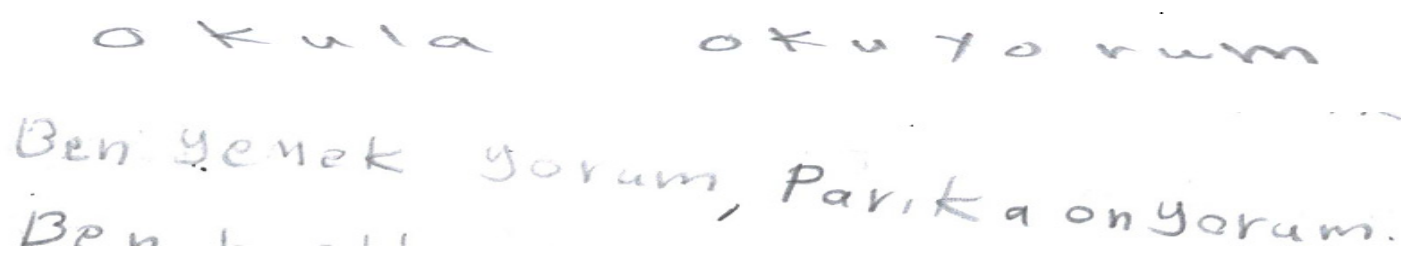

Using an ablative case marker rather than a locative case marker

A2:

$$
\text { Askerler dág dançat, stilar }
$$

Table 6 shows the frequency of the errors in ablative case markers in the texts formed by the students in A1 and A2.

Table 6. The frequency of the errors in ablative case markers by the students in A1 and A2

\begin{tabular}{lll}
\hline The errors in ablative case markers & A1(f) & A2(f) \\
\hline Lack of an ablative case marker & 0 & 3
\end{tabular}

As seen Table 6, there was not any error in the ablative case markers made by the students in A1. All the three errors in the ablative case markers in the texts formed by the students in A2 were due to the lack of an ablative case marker. Below, there are some examples from the texts formed by the students in relation to the errors in the ablative case markers:

Lack of an ablative case marker

A2:

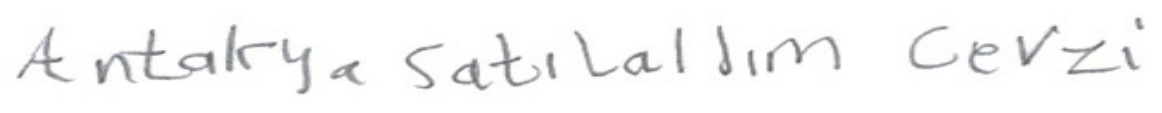

\section{Conclusion and Discussion}

This study, which aims to determine the errors in the case markers in the texts formed by Syrian students learning Turkish, analysed the written texts by a total of 60 students, including 30 students in A1 and those in A2. The total number of words used in the texts formed by the students in A1 was 730 whereas the total number of words used in the texts formed by the students in A2 was 970 . According to the results of the study, there was a total of 58 errors in the case markers in the texts formed by the students in A1 while there was a total of 90 errors in the case markers in the texts formed by the students in A2. The study revealed that in terms of the total number of words used by the students, the students in A1 made 8 errors in case markers for each 100 words whereas those in A2 made 9.3 errors in case markers for each 100 words. It is expected that the students in A2 make less errors than those in A1. On the other hand, given that those in $\mathrm{A} 2$ attempted to write a longer text than those in A1 do, their possibility of making an error would potentially increase. Altaş Özkan (1992) reached the same conclusion, pointing out that the subject becomes more difficult and the possibility of making an error increases when a student switches from simple and concrete sentences to more abstract sentences and more complex structures. It is notable that the students in A1 made the most errors in the genitive case markers. Accordingly, it can be stated that the students have difficulty in possessive construction. In a similar way, Yılmaz Atagül and Yahşi Cevher (2015) emphasized that the students make errors in the genitive case markers as well. It is remarkable that the students in A2 made the most errors in locative case markers. The students attempted to mean that they were in a place, without using locative case markers in their sentences. Some studies, which were carried out differently from this study, (Islıoğlu, 2014; Yağmur Şahin, 2013; Güven, 2007) revealed that the students have difficulty in accusative case markers. It might be argued that such difference results from a difference in the age and educational levels of the students. While the above-mentioned studies were performed in Turkish and Foreign Language Research and Application Center (TÖMER) with the students preparing for the university admission test, this study was conducted with the students at primary and secondary school level, who study at TECs.

Notably, there was no error in the ablative case markers in the texts produced by the students in A1. The study further found that the number of such errors made by the students in A2 was very low. Similarly, the studies in the literature (Güven, 2007; Altaş Özkan, 1992) reported that, in terms of the case markers, the participants made the least errors in the ablative case markers.

Given the errors made by the students in this study, it may be claimed that students have difficulty in case markers, 
which is an important subject of grammar. When the students employed the case markers, they frequently and mistakenly used a case marker instead of the necessary one. The reason may be the misconceptions of the students in relation to the 'meaning.' Demirci (2016) stated that the errors made by the students result from the abstract structure of case markers. Another reason might be that the native language of the students has a different structure than Turkish does. In a similar way, Mavaşoğlu and Tüm (2010) articulated that the most common problem among foreign students is case markers and argued that this stems from the difference between the native language of students and the language they learn.

In line with the results of the study, it is possible to make the following suggestions:

- It is necessary for foreign students to comprehend the meaning of case markers and the functions of these markers. The aspect of 'meaning' should not be disregarded in teaching these markers.

- The data of this study were obtained from the texts produced by the students studying at TECs. It is essential to take into consideration the errors in case markers (particularly resulting from a different native language) in developing the curriculum followed by TECs.

- The inclusion of some practices to enable the students to have a general idea of and to learn the grammar and features of Turkish in the course books in TECs may contribute to the elimination of such errors.

\section{References}

Aksan, D. (1979). Encountered some difficulties and mistakes by foreign people during learning Turkish. Hacettepe University Journal of the Faculty of Letters, 6(1-2), 259-261.

Altaş, Ö. A. (1992). Case markers mistakes made by foreigners during learning Turkish and evaluation of this issue. (Master's thesis, Gazi University, Ankara, Turkey). Retrieved from https://tez.yok.gov.tr/UlusalTezMerkezi

Arhan, A. (2015). As Turkish language learners, Egyptian students' case affix errors in writing. (Master's thesis, Başkent University, Ankara, Turkey). Retrieved from https://tez.yok.gov.tr/UlusalTezMerkezi

Bölükbaş, F. (2011). An evaluation of Arab students Turkish writing skills. Turkish Studies-International Periodical for the Languages, Literature and History of Turkish or Turkic, 6(3), 1357-1367. https://doi.org/10.7827/TurkishStudies.2415

Candaş Karababa, C. (2009). Teaching Turkish as a foreign language and problems encountered. Ankara University Journal of Faculty of Educational Sciences, 42(2), 265-277. https://doi.org/10.1501/Egifak_0000001185

Demirci, M., \& Dinçaslan, M. F. (2016). The use of valence of Syrian students learning Turkish as a foreign language. Journal of Theory and Pratice in Education, 12(5), 1011-1040.

Directorate General of Migration Management (2016). Turkey immigration report. http://www.goc.gov.tr/files/files/2016_yiik_goc_raporu_haziran.pdf/Date accessed: 20.05.2017

Duman, G. B. (2013). The errors of noun case suffixes Kyrgyz students make while learning Turkish of Turkey and solutions to them. Journal of Language and Literature Education, 2(5), 82-94.

Education Reform Initiative (2017). http://www.egitimreformugirisimi.org Data accessed:10.07.2017

Güven, E. (2007). A study on the analysis of the errors by foreigners in learning Turkish regarding nominal case suffixes and some suggestions to eliminate these errors. (Master's thesis, Dokuz Eylül University, İzmir, Turkey). Retrieved from https://tez.yok.gov.tr/UlusalTezMerkezi

İnal, S. (2006). An analysis of the problems in teaching written expressions in the English language. Journal of Language and Linguistic Studies, 2(2).

Islıoğlu, S. (2014). Mistakes and solution offers regarding the use of object case suffix in teaching Turkish as a foreign language. Route Educational and Social Science Journal, 1(2), 101-115. https://doi.org/10.17121/ressjournal.53

Kan, M. O., \& Tiryaki, E. N. (2015). Problems of Turkish teacher candidates on constituting text. Mersin University Journal of the Faculty of Education, 11(2). https://doi.org/10.17860/efd.19368

Korkmaz, Z. (2009). Turkey Turkish grammer (Morphology). Ankara: Türk Dil Kurumu Yayınları

Mavaşoğlu, M., \& Tüm, G. (2010). Çukurova University practices in order to educating Turkish as a foreign language, encountered problems and solutions. http://turkoloji.cu.edu.tr/ Date accessed:15.06.2017

Melanlıoğlu, D. (2012). The views of instructors that teach Turkish to foreigners on teaching case-endings: A qualitative study. Turkish Studies-International Periodical for the Languages, Literature and History of Turkish or Turkic, 7(4), 2401-2411. https://doi.org/10.7827/TurkishStudies.4121 
Merriam, S. B. (2009). Oualitative research: A guide to design and implementation. San Francisco, CA: Jossey-Bass.

Tunçel, H. (2013). The effects on the success of teaching of locative suffixes using by visual material in teaching Turkish as a foreign language. The Journal of Academic Social Science Studies, 6(7), 1109-1125. https://doi.org/10.9761/JASSS1767

Yağmur, Ş. E. (2013). Affix errors in written expression of Turkish as a foreign language learners. Journal of History School, 6, 433-449. https://doi.org/10.14225/Joh283

Yıldırım, A., \& Şimşek, H. (2016). Qualitative research methods in social sciences. Ankara, Turkey: Seçkin Yayınları.

Yıldırım, H. Ç. (2011). Student opinions regarding the Turkish grammar and nominal case suffixes in teaching Turkish as a foreign language. (Master's thesis, Gazi University, Ankara, Turkey). Retrieved from https://tez.yok.gov.tr/UlusalTezMerkezi

Yılmaz, A. Y., \& Yahşi, C. Ö. (2015). Teaching of Turkish as a foreign language and its problematics on positional suffix (Sakarya University Example). Turuk International Language and Folklore Researches Journal, 3(5), 294-332.

\section{Copyrights}

Copyright for this article is retained by the author(s), with first publication rights granted to the journal.

This is an open-access article distributed under the terms and conditions of the Creative Commons Attribution license which permits unrestricted use, distribution, and reproduction in any medium, provided the original work is properly cited. 